\title{
Ionizing Radiation Alters Human Embryonic Stem Cell Properties and Differentiation Capacity by Diminishing the Expression of Activin Receptors
}

\author{
Sabine Luft, Onetsine Arrizabalaga, Ireen Kulish, ${ }^{1,2}$ Elena Nasonova, ${ }^{1,3}$ Marco Durante,, ${ }^{1, *}$ \\ Sylvia Ritter, and Insa S. Schroeder ${ }^{1}$
}

Exposure of the embryo to ionizing radiation (IR) is detrimental as it can cause genotoxic stress leading to immediate and latent consequences such as functional defects, malformations, or cancer. Human embryonic stem (hES) cells can mimic the preimplantation embryo and help to assess the biological effects of IR during early development. In this study, we describe the alterations $\mathrm{H} 9 \mathrm{hES}$ cells exhibit after X-ray irradiation in respect to cell cycle progression, apoptosis, genomic stability, stem cell signaling, and their capacity to differentiate into definitive endoderm. Early postirradiation, hES cells responded with an arrest in G2/M phase, elevated apoptosis, and increased chromosomal aberrations. Significant downregulation of stem cell signaling markers of the TGF beta-, Wnt-, and Hedgehog pathways was observed. Most prominent were alterations in the expression of activin receptors. However, hES cells responded differently depending on the culture conditions chosen for maintenance. Enzymatically passaged cells were less sensitive to IR than mechanically passaged ones showing fewer apoptotic cells and fewer changes in the stem cell signaling $24 \mathrm{~h}$ after irradiation, but displayed higher levels of chromosomal aberrations. Even though many of the observed changes were transient, surviving hES cells, which were differentiated 4 days postirradiation, showed a lower efficiency to form definitive endoderm than their mock-irradiated counterparts. This was demonstrated by lower expression levels of SOX17 and microRNA miR-375. In conclusion, hES cells are a suitable tool for the IR risk assessment during early human development. However, careful choice of the culture methods and a vigorous monitoring of the stem cell quality are mandatory for the use of these cells. Exposure to IR influences the stem cell properties of hES cells even when immediate radiation effects are overcome. This warrants consideration in the risk assessment of radiation effects during the earliest stages of human development.

Keywords: ionizing radiation, early human development, embryonic stem cells, pluripotency, activin receptors, definitive endoderm

\section{Introduction}

$\mathrm{P}$ RESERVATION OF GENOMIC INTEGRITY and the ability to form any tissue of the body are of paramount importance in human development as genomic instability or inadequate cell differentiation in utero may lead to immediate and latent consequences such as functional defects, malformations, or cancer. Ionizing radiation (IR) is known to be one of the leading causes of genotoxic stress, but is inevitable not only due to natural sources but also due to its increasing use in contemporary medicine. However, a careful assessment of the risk IR imposes on the early embryo is hampered by scarce epidemiological data and suboptimal (animal) model systems [1,2].
Human embryonic stem (hES) cells that have been derived from the inner cell mass of preimplantation embryos represent a perfect model to mimic early human development as, like their in vivo counterparts, they can be propagated indefinitely and can be differentiated in vitro into all cells of the body. Thus, the exact mechanisms underlying the IR effects during early human development can be examined in detail, but studies using hES cells are scarce.

While many groups concordantly report about early apoptosis of mouse and hES cells upon irradiation with sparsely ionizing gamma- or X-rays [3-6], pluripotency seemed not to be affected [4,6,7]. Likewise, teratoma formation as a measure of pluripotency and the spontaneous differentiation

\footnotetext{
${ }^{1}$ Department of Biophysics, GSI Helmholtz Center for Heavy Ion Research, Darmstadt, Germany.

${ }^{2}$ Technical University Darmstadt, Darmstadt, Germany.

${ }^{3}$ Laboratory of Radiation Biology, Joint Institute for Nuclear Research, Dubna, Russia.

*Current affiliation: Trento Institute for Fundamentals Physics Applications (TIFPA), Trento, Italy.
}

(C) Sabine Luft et al. 2017; Published by Mary Ann Liebert, Inc. This article is available under the Creative Commons License CC-BY-NC (http://creativecommons.org/licenses/by-nc/4.0). This license permits non-commercial use, distribution and reproduction in any medium, provided the original work is properly cited. Permission only needs to be obtained for commercial use and can be done via RightsLink. 
capacity of ES cells was still observed [6]. However, we and others observed differences in the cardiac differentiation capacity of ES cells after exposure to sparsely IR $[6,8,9]$ that was even more pronounced after treatment with densely ionizing C-ions [8].

These somewhat contradicting findings may not only stem from variations in the radiation type and dosage but also from the quality of the ES cells used. Indeed, the usage of hES cells comes with a caveat as suboptimal or prolonged culture can lead to genomic variations [10] altering the stem cell properties and differentiation capabilities. For example, enzymatic passaging techniques such as trypsin passage were reported to be associated with abnormalities of chromosomes 12 and 17 in hES cells [11], while others did not detect differences in the genomic stability of hES cells when comparing mechanical with collagenase IV based dissociation methods [12]. However, culture-adapted, karyotypically abnormal hES cells often exhibit shorter population doubling times and increased cloning efficiencies [13]. Such culture-adapted hES cells also show altered differentiation patterns such as a reduced capability to produce extraembryonic endoderm, which was judged by the loss of induction of alpha-fetoprotein (AFP) [14].

To our knowledge, our study is the first to compare the response to X-ray irradiation of enzymatically passaged (EP) hES cells with that of mechanically passaged (MP) cells to clearly define the impact of X-ray irradiation on hES cells. Thus, for the first time, this study takes into account the culture methods and their suitability for radiation risk assessment purposes. Analytic parameters comprised cell cycle progression, apoptosis, genomic stability, stem cell signaling, and the cells' capacity to differentiate into definitive endoderm (DE) that will eventually form organs such as the lung, liver, and pancreas.

\section{Methods}

\section{hES cell culture}

WA09 (H9, passage 26) hES cells were obtained from WiCell Research Institute, Inc. and further cultured under standard conditions $\left(5 \% \mathrm{CO}_{2}\right.$, ambient $\left.\mathrm{O}_{2}, 37^{\circ} \mathrm{C}\right)$ on irradiated, mitotically inactive PMEF-NL embryonic fibroblasts (23.150 cells $/ \mathrm{cm}^{2}$; Millipore) in KnockOut ${ }^{\mathrm{TM}}$ DMEM with 20\% KnockOut Serum Replacement (Thermo Scientific), $1 \mathrm{mM}$ stable glutamine (PAA Laboratories), $1 \times$ nonessential amino acids (Biochrom), $100 \mu \mathrm{M}$ b-mercaptoethanol (Carl
Roth), $50 \mathrm{U} / \mathrm{mL}$ penicillin, and $50 \mu \mathrm{g} / \mathrm{mL}$ streptomycin (H9medium). For the daily medium exchange, basic fibroblast growth factor (bFGF) (Peprotech) was added to give a final concentration of $10 \mathrm{ng} / \mathrm{mL}$.

Cells were passaged every 7 days either enzymatically or mechanically. For EP, the medium was aspirated, $1 \mathrm{~mL}$ dispase $(6 \mathrm{U} / \mathrm{mL}$; BD Biosciences) was added, and cells were incubated for $3-7 \mathrm{~min}$ at $37^{\circ} \mathrm{C}$. Detached colonies were suspended in $\mathrm{H} 9$ medium and centrifuged for $3 \mathrm{~min}$ at $200 \mathrm{~g}$. After supernatant removal, cells were resuspended in $\mathrm{H} 9$ medium with bFGF and split 1:3-1:5. For mechanical passaging (MP), 15-20 H9 colonies were chosen due to typical hES cell morphologic characteristics and microdissected into 9-12 squares with a sterile no. 21 scalpel using a microscope (100× magnification) in an open laminar flow cabinet. The dissected cell clusters were transferred to a new petri dish $\left(21.6 \mathrm{~cm}^{2}\right)$ containing $3 \mathrm{~mL} \mathrm{H} 9$ medium with bFGF.

\section{hES cell irradiation}

X-ray irradiation was performed using an Isovolt DS1 Xray tube (Seifert, Ahrensburg, Germany) equipped with a $7 \mathrm{~mm} \mathrm{BE}, 1 \mathrm{~mm} \mathrm{Al}$, and $1 \mathrm{~mm} \mathrm{CU}$ filter system to absorb soft X-rays. Voltage and current settings were $250 \mathrm{kV}$ and $16 \mathrm{~mA}$, respectively. The medium was exchanged immediately after irradiation, and the cells were returned to the incubator within $30 \mathrm{~min}$. For cell cycle, apoptosis, stem cell signaling, and chromosome analyses, MP or EP H9 hES cells were harvested $24 \mathrm{~h}$ and 4 days postirradiation. To assess the differentiation capacity of MP H9 cells surviving irradiation, radiation treatment was performed at day 4 , two days before transferring the cells to a feeder-free culture (Fig. 1) allowing them to recover before being passaged. All irradiated samples were compared to sham-treated controls.

\section{Cell cycle analysis and apoptosis assay using flow cytometry}

For cell cycle and apoptosis analyses, H9 cells were cultured on Matrigel for two passages to deplete MEF feeder cells. The cell cycle duration was analyzed using the Click-iT $^{\circledR}$ EdU Alexa Fluor ${ }^{\circledR} 488$ Flow Cytometry Assay Kit (Invitrogen) according to the manufacturer's instructions. Apoptotic cells were identified by immunochemical staining of activated caspase-3 (CASP-3) using a FITC Active caspase-3 Apoptosis Kit (BD Biosciences) according to the manufacturer's protocol. A medium exchange was performed

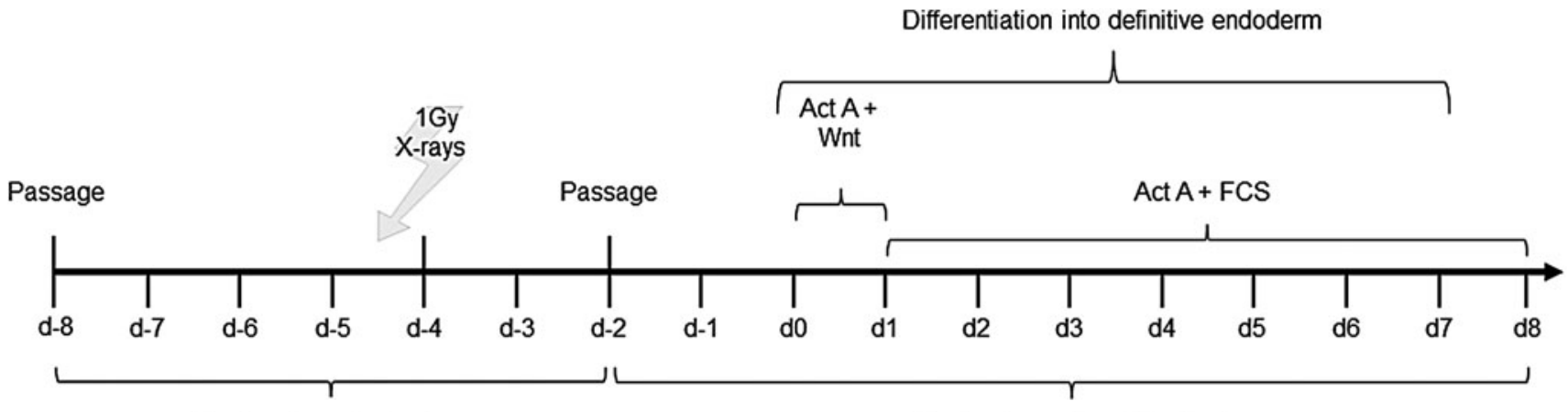

Feeder-dependent culture

Feeder-free culture (Matrigel)

FIG. 1. Differentiation and irradiation scheme. 
Table 1. Radiation-InduCed Chromosomal Alterations: Numerical ABERRATIONS

\begin{tabular}{lcccc}
\hline Sample & $\begin{array}{c}\text { Radiation } \\
\text { dose } \\
{[G y]}\end{array}$ & $\begin{array}{c}\text { Harvesting } \\
\text { time }\end{array}$ & $\begin{array}{c}\text { Passaging } \\
\text { method }\end{array}$ & $\begin{array}{c}\text { Tetraploid } \\
\text { cells/cells } \\
\text { counted (\%) }\end{array}$ \\
\hline Control & 0 & $24 \mathrm{~h}$ & $\mathrm{MP}$ & $13 / 1190(1.1)$ \\
Control & 0 & 4 days & MP & $4 / 200(2.0)$ \\
X-rays & 1 & $24 \mathrm{~h}$ & MP & $0 / 158(0)$ \\
X-rays & 1 & 4 days & MP & $0 / 200(0)$ \\
Control & 0 & 24 h & EP & $3 / 869(0.4)$ \\
Control & 0 & 4 days & EP & $0 / 380(0)$ \\
X-rays & 1 & 24 h & EP & $1 / 280(0.4)$ \\
X-rays & 1 & 4 days & EP & $5 / 315(1.6)$ \\
\hline
\end{tabular}

before the irradiation of cells to exclude any apoptosis not caused by the radiation treatment. Additional staining of the nuclei with $1 \mu \mathrm{g} / \mathrm{mL}$ DAPI for $15 \mathrm{~min}$ allowed the simultaneous cell cycle analysis. Stained cells were measured in a BD FACSCanto II flow cytometer using the BD FACSDiva ${ }^{\mathrm{TM}}$ v7.0 software. Data analyses were performed with the software FlowJo v7.6.5 for cell cycle experiments and v10 for apoptosis studies. The Watson pragmatic algorithm was used to obtain probability distributions for the cells in G1, S, and $\mathrm{G} 2 / \mathrm{M}$ phase of the cell cycle.

\section{Cytogenetic analyses}

For cytogenetic analysis, cells were harvested $24 \mathrm{~h}$ and 4 days after $\mathrm{X}$-ray exposure representing cells at the first and fourth postirradiation division, respectively. Each sampling was preceded by a 2 -h colcemid treatment $(0.1 \mu \mathrm{g} /$ $\mathrm{mL}$ ) to accumulate metaphase cells. Chromosome spreads were prepared according to standard procedures and stained with the 24XCyte human multicolor FISH probe (MetaSystems, Altlussheim, Germany) following the instructions of the manufacturer. Samples were analyzed using an Axio Imager Z1 microscope (Zeiss) and ISIS software (MetaSystems) [15].

All types of structural chromosome aberrations were recorded and classified according to the mPAINT system [16]. As asynchronously growing cell populations were irradiated, structural aberrations comprise both chromosome- and chromatid-type aberrations [17]. Each category can be further divided into breaks (not associated with an exchange) and simple and complex exchanges. While simple exchanges result from the misrejoining of two breaks, complex exchanges originate from three or more breaks in two or more chromosomes. Due to low numbers, aberration subgroups were pooled together with the total number of breakpoints underlying the observed damages. In addition, numerical aberrations were recorded. All data are shown in Tables 1 and 2. The distribution of breakpoints among chromosomes is given in Supplementary Table S1 (Supplementary Data are available online at www.liebertpub.com/scd) for breaks (B) and exchanges $(\mathrm{Ex})$, respectively.

\section{hES cell differentiation into $D E$}

Differentiation of MP H9 hES cells into DE was performed in three independent experiments (using cells of passage 64,66 , and 68 , respectively) according to reference [18] as depicted in Fig. 1. Briefly, 2 days prior (d-2) to differentiation initiation $(\mathrm{d} 0)$, cells were plated on growth factor-reduced Matrigel (1:25) in PMEF-NL conditioned $\mathrm{H} 9$ medium with $4 \mathrm{ng} / \mathrm{mL}$ bFGF. Control cells were plated in a ratio of $1: 1$ and irradiated cells in a ratio of $2: 1$. On day 0 , medium was switched to RPMI/KnockOut DMEM with L-glucose, $50 \mathrm{U} / \mathrm{mL}$ penicillin, and $50 \mu \mathrm{g} / \mathrm{mL}$ streptomycin. One hundred nanograms per milliliter recombinant human Activin A, $25 \mathrm{ng} / \mathrm{mL}$ recombinant human $\mathrm{Wnt} 3 \mathrm{a}$, and $0.2 \%$ FCS were added as indicated in Fig. 1.

\section{Total RNA and microRNA expression analyses using quantitative reverse transcription polymerase chain reaction}

To assess transcription of pluripotency and differentiation markers, total RNA, including microRNA, was isolated from cell lysates taken at different time points as indicated elsewhere. Briefly, cells were lysed in $700 \mu \mathrm{L}$ QIAzol lysis reagent after a wash step with PBS, incubated for $5 \mathrm{~min}$ at room temperature, and stored at $-80^{\circ} \mathrm{C}$. RNA was isolated using the miRNeasy Mini Kit (Qiagen) according to the manufacturer's protocol. Two microgram of total RNA was reversetranscribed applying the Thermo Scientific RevertAid RT Kit that uses random hexamer primers for first strand cDNA generation.

Quantitative RT-PCR was carried out in triplicates with HOT FIREPol ${ }^{\circledR}$ EvaGreen ${ }^{\circledR}$ qPCR Mix PLUS ROX (Solis BioDyne, Estonia) and a StepOnePlus ${ }^{\mathrm{TM}}$ Real-Time PCR System (ABI Biosciences, Thermo Scientific) using the

Table 2. Radiation-Induced Chromosomal Alterations: Structural Aberrations

\begin{tabular}{|c|c|c|c|c|c|c|c|c|c|c|}
\hline \multirow[b]{2}{*}{ Sample } & \multirow{2}{*}{$\begin{array}{c}\text { Radiation } \\
\text { dose } \\
{[G y]}\end{array}$} & \multirow{2}{*}{$\begin{array}{l}\text { Harvesting } \\
\text { time }\end{array}$} & \multirow[b]{2}{*}{$\begin{array}{l}\text { Passaging } \\
\text { method }\end{array}$} & \multirow{2}{*}{$\begin{array}{c}\text { No. of } \\
\text { cells } \\
\text { analyzed }\end{array}$} & \multirow{2}{*}{$\begin{array}{l}\text { No. of } \\
\text { aberrant } \\
\text { cells }\end{array}$} & \multirow{2}{*}{$\begin{array}{c}\text { Aberrations/ } \\
100 \text { cells } \\
{[\%]}\end{array}$} & \multirow{2}{*}{$\begin{array}{l}\text { Breakpoints/ } \\
100 \text { cells }\end{array}$} & \multicolumn{3}{|c|}{ Aberrations/100 cells } \\
\hline & & & & & & & & Breaks & $\begin{array}{c}\text { Simple } \\
\text { exchanges }\end{array}$ & $\begin{array}{c}\text { Complex } \\
\text { exchanges }\end{array}$ \\
\hline Control & 0 & $24 \mathrm{~h}$ & MP & 424 & 4 & 0.9 & 0.9 & 0.9 & 0 & 0 \\
\hline Control & 0 & 4 days & MP & 195 & 0 & 0 & 0 & 0 & 0 & 0 \\
\hline X-rays & 1 & $24 \mathrm{~h}$ & MP & 128 & 13 & 16.4 & 28.9 & 4.7 & 10.9 & 0.8 \\
\hline X-rays & 1 & 4 days & MP & 197 & 3 & 1.5 & 2.5 & 0.5 & 1.0 & 0 \\
\hline Control & 0 & $24 \mathrm{~h}$ & $\mathrm{EP}$ & 440 & 2 & 0.5 & 0.7 & 0.2 & 0.2 & 0 \\
\hline Control & 0 & 4 days & $\mathrm{EP}$ & 281 & 3 & 1.1 & 1.1 & 1.1 & 0 & 0 \\
\hline X-rays & 1 & $24 \mathrm{~h}$ & EP & 236 & 35 & 21.2 & 39.8 & 8.1 & 10.6 & 2.5 \\
\hline X-rays & 1 & 4 days & EP & 315 & 9 & 2.9 & 5.4 & 1.3 & 0.6 & 1.0 \\
\hline
\end{tabular}


following settings: $15 \mathrm{~min}$ at $95^{\circ} \mathrm{C}$ for polymerase activation and 40 cycles at $95^{\circ} \mathrm{C} / 15 \mathrm{~s}, 60^{\circ} \mathrm{C} / 1 \mathrm{~min}$. A melt curve analysis was included in every PCR for quality assessment. 18sRNA was used as a reference for normalization. Primer sequences are found in Supplementary Table S2.

For microRNA expression analyses, $1 \mu \mathrm{g}$ total RNA was reverse-transcribed using the miScript ${ }^{\circledR}$ II RT Kit (Qiagen) and the provided miScript HiFlex Buffer. Quantification of miR375 was performed using the miScript $\mathrm{SYBR}^{\circledR}$ Green PCR Kit with the Hs_miR-375_2 and Hs_SNORD25_11 (reference for normalization) miScript Primer Assays, respectively (all reagents: Qiagen). miRNA quantification required the following three-step cycling conditions: $15 \mathrm{~min}$ at $95^{\circ} \mathrm{C}$ for polymerase activation and 40 cycles at $94^{\circ} \mathrm{C} / 15 \mathrm{~s}, 55^{\circ} \mathrm{C} / 30 \mathrm{~s}$, and $70^{\circ} \mathrm{C} / 30 \mathrm{~s}$ followed by a melt curve analysis. Standard curves were generated from human fetal liver or $\mathrm{H} 9$ cell total RNA. Quantification according to the relative standard curve method was performed applying the ABI StepOne Software v2.3.

\section{Stem cell signaling mRNA array analyses}

Using the $\mathrm{RT}^{2}$ First Strand Kit (Qiagen), $1 \mu \mathrm{g}$ total RNA was converted into cDNA according to the manufacturer's protocol. To quantitatively assess characteristic markers of stem cell signaling, real-time PCR Arrays were performed $\left(\mathrm{RT}^{2}\right.$ Profiler ${ }^{\mathrm{TM}}$ PCR Array Human Stem Cell Signaling, PAHS-047Z; Qiagen). Cycling conditions were as follows: $10 \mathrm{~min}$ at $95^{\circ} \mathrm{C}$ and 40 cycles at $95^{\circ} \mathrm{C} / 15 \mathrm{~s}$ and $60^{\circ} \mathrm{C} / 1 \mathrm{~min}$. Data were processed using the $\mathrm{RT}^{2}$ Profiler PCR Array Data Analysis Web portal (www.qiagen.com/de/shop/genes-andpathways/data-analysis-center-overview-page, accessed July $6,2016)$. Details regarding the data analysis can be found in the $\mathrm{RT}^{2}$ Profiler Array Data Analysis v3.5 Handbook (www .qiagen.com/de/shop/genes-and-pathways/data-analysis-centeroverview-page/rt2-profiler-pcr-arrays-data-analysis-center/ ?instrument $=$ ABI_StepOnePlus $\&$ format $=$ C\&catno $=$ PAHS 047Z, accessed July 6, 2016).

\section{Statistical analysis}

Statistical significance was calculated based on Fisher's exact test for cytogenetic analyses and Student's $t$-test for gene expression analyses. Error bars represent the standard deviation.

\section{Results}

\section{Cell cycle progression and cell survival}

Pluripotency and the propensity of hES cells to differentiate into a certain lineage are associated with cell cycle regulation [19]. Thus, the cell cycle progression of nonirradiated $\mathrm{H} 9$ control cells and those treated with $1 \mathrm{~Gy} \mathrm{X}$-rays was analyzed. Consistent with findings by others [20,21], H9 cells displayed a cell cycle length of $\sim 16-20 \mathrm{~h}$ (Supplementary Fig. S1). A transient G2/M-phase arrest could be observed $7 \mathrm{~h}$ after irradiation with $1 \mathrm{~Gy} \mathrm{X}$-rays (data not shown). However, $24 \mathrm{~h}$ after radiation treatment, the cells resumed to normal cell cycle progression, and the fraction of cells in G2/M-phase was similar to that of control cells (Fig. 2A) irrespective of the culture method used.

Apoptosis as judged by the fraction of cells positive for active caspase-3 (CASP-3) (Fig. 2B) was generally higher in MP cells than in EP cells. Twenty-four hours after
FIG. 2. Cell cycle progression, apoptosis, and morphology after irradiation. (A) Fraction of cells in G2/M phase in controls and irradiated hES cells after $24 \mathrm{~h}$ in EP and MP populations. (B) Fraction of caspase- 3 positive apoptotic cells in EP and MP populations $24 \mathrm{~h}$ postirradiation compared with their mock-irradiated counterparts. (C) Cell morphology of controls and irradiated hES cells at day 0 (4 days postirradiation). hES, human embryonic stem.

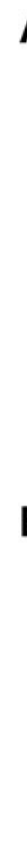

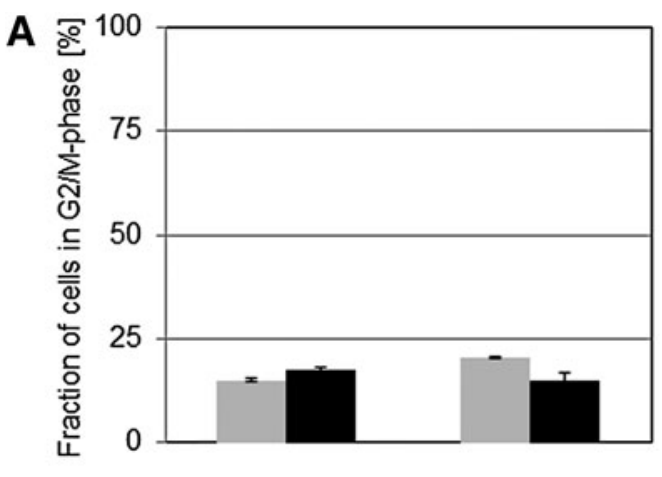

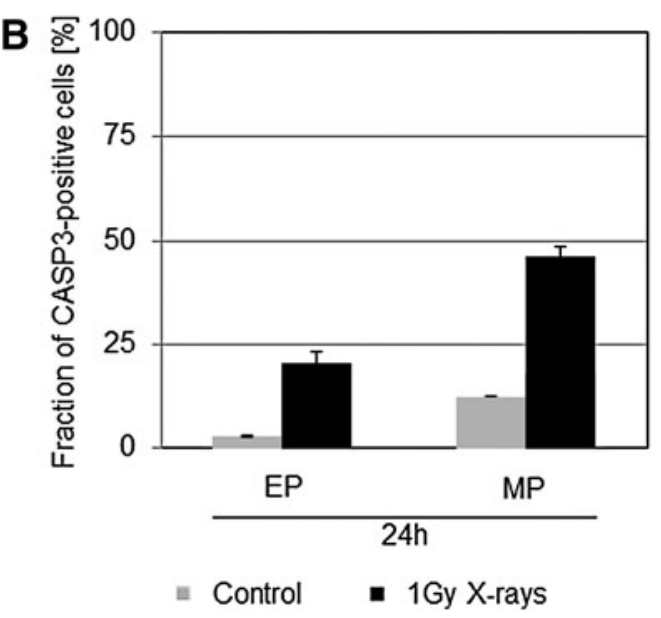

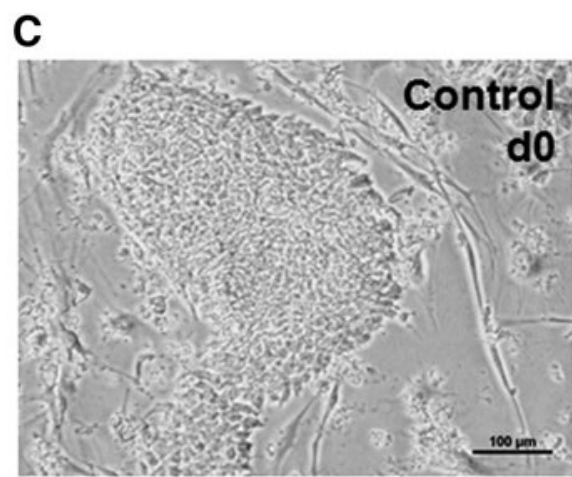

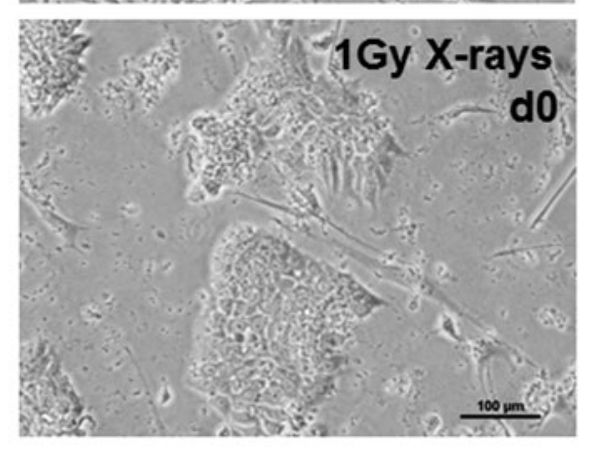


irradiation, a substantial higher percentage of CASP-3positive cells was still observed in the cells subjected to $1 \mathrm{~Gy}$ X-rays compared to the controls. In accordance, 4 days after irradiation, the colony size was consistently smaller in X-ray treated cells than in nonirradiated samples (Fig. 2C). Thus, for further differentiation experiments, irradiated cells from two plates were pooled to assure that diverging cell densities could not contribute to differences in the differentiation behavior/efficiency.

\section{Chromosomal aberrations}

Chromosomal alterations were analyzed $24 \mathrm{~h}$ and 4 days after irradiation in MP and EP cells using multicolor

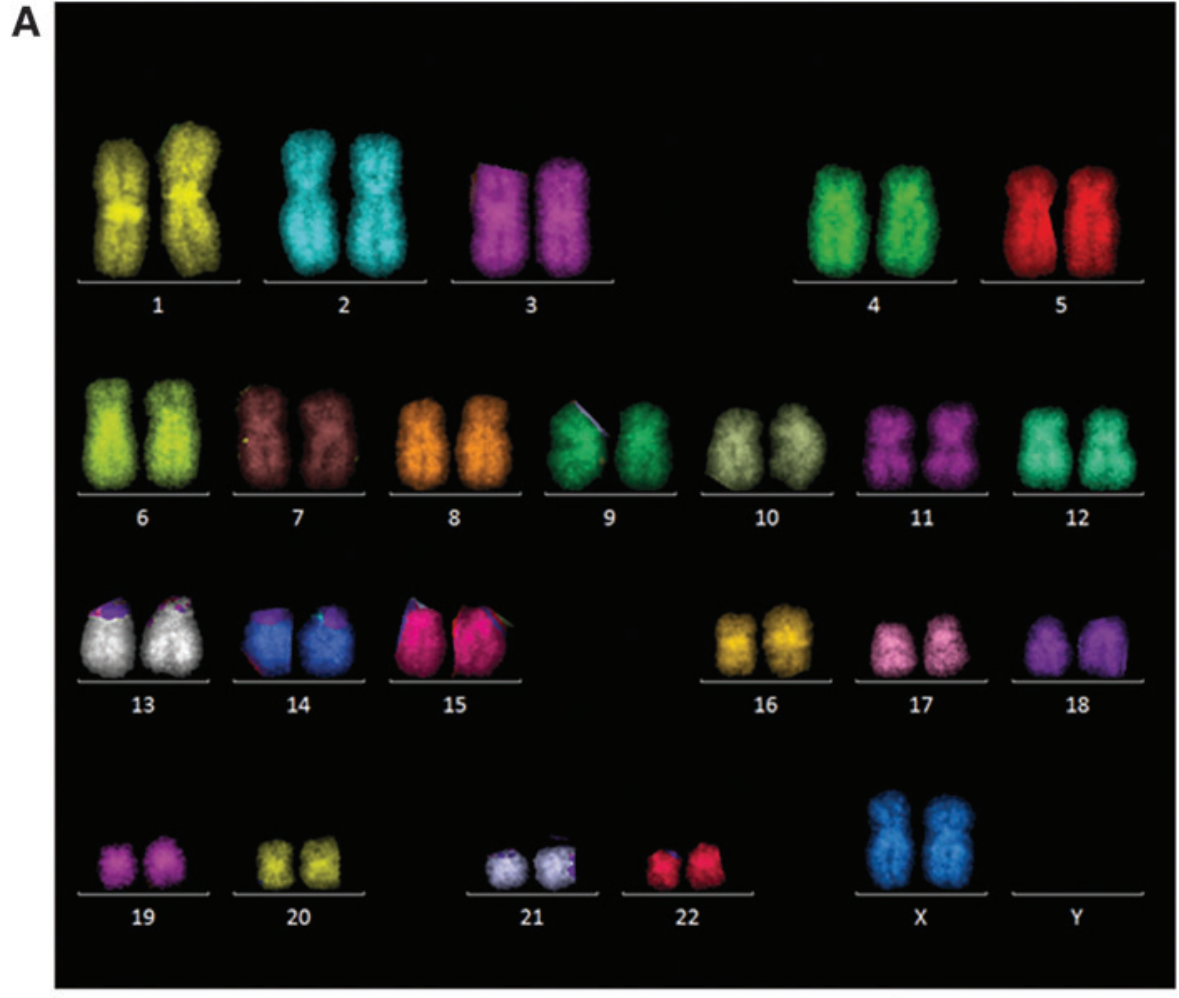

B

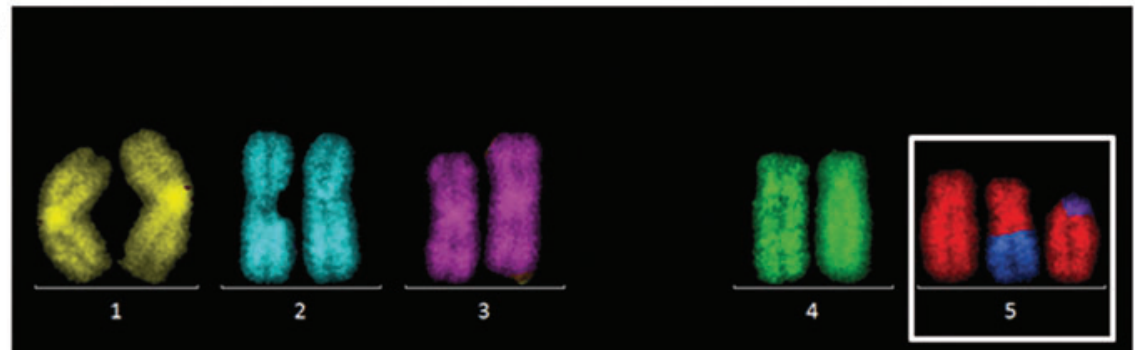

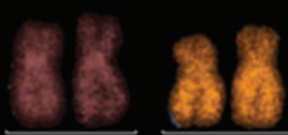

8
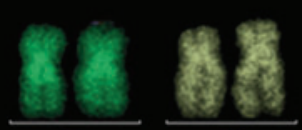

10

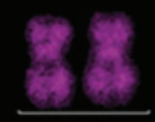

11

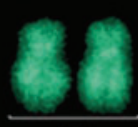

12

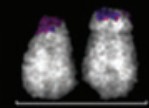

13

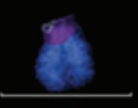

14

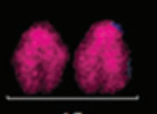

15

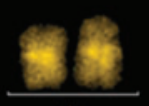

16
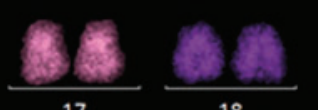

18

FIG. 3. Representative karyograms of $\mathrm{H} 9$ cells after mFISH staining. (A) Cell with a normal karyotype. (B) Cell with a simple exchange (ie, a reciprocal translocation between chromosome 5 and 14, outlined by white box). The exchange was detected in a sample (MP) harvested $24 \mathrm{~h}$ after X-ray exposure. mFISH, multicolor fluorescence in situ hybridization. 
FIG. 4. Stem signaling array: clustergrams. A two dimensional clustering is shown for control and irradiated cells originating from $\mathrm{EP}$ and MP populations $24 \mathrm{~h}$ postirradiation. The minimum magnitude of gene expression for a given gene over all samples in one clustergram is indicated in green, while the maximum magnitude is indicated in red.

\section{Enzymatically passaged cells:}
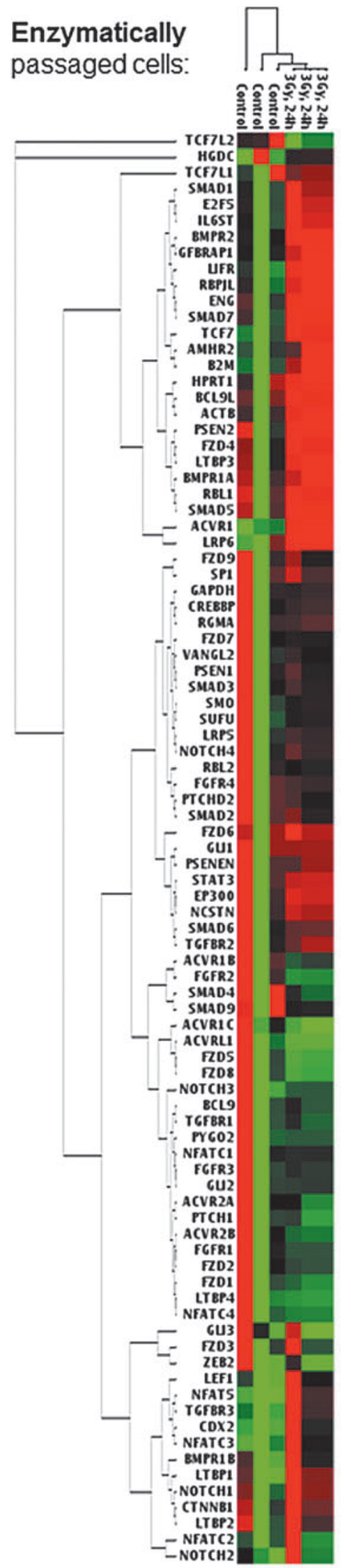

Manually passaged cells:

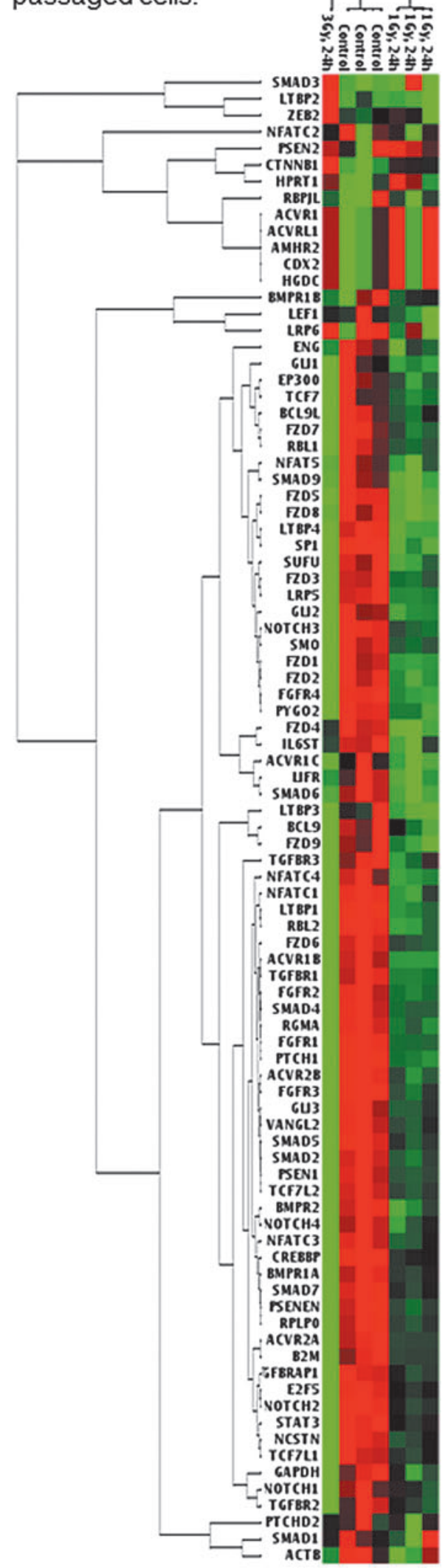

Magnitude of gene expression

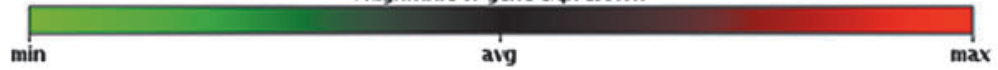


fluorescence in situ hybridization (mFISH) (Tables 1 and 2). Figure 3 shows typical karyograms of a normal and an aberrant cell. No aneuploidy (eg, trisomy as reported by reference [10] or [14]) was observed in any of the samples analyzed. The fraction of tetraploid cells did not exceed $2 \%$ and was not correlated to the radiation treatment (Table 1). In control cells, structural aberrations comprised predominately simple breaks (Table 2). One simple exchange (translocation) was found in the $24 \mathrm{~h}$ EP control while none of the controls displayed complex exchanges. Twenty-four hours after irradiation, the overall number of aberrant cells increased and was consistently higher in the EP cells than in the MP cells. Likewise, the frequency of complex aberrations was higher in EP cells compared with their MP counterparts. During the subsequent cell divisions, the number of aberrations declined, that is, 4 days after irradiation the aberration yield was lower than at $24 \mathrm{~h}$. The distribution of breakpoints among chromosomes is summarized in Supplementary Table S1.

\section{Changes in stem cell signaling pathways}

The mRNA expression of 84 factors known to regulate stem cell signaling and pluripotency was examined using real-
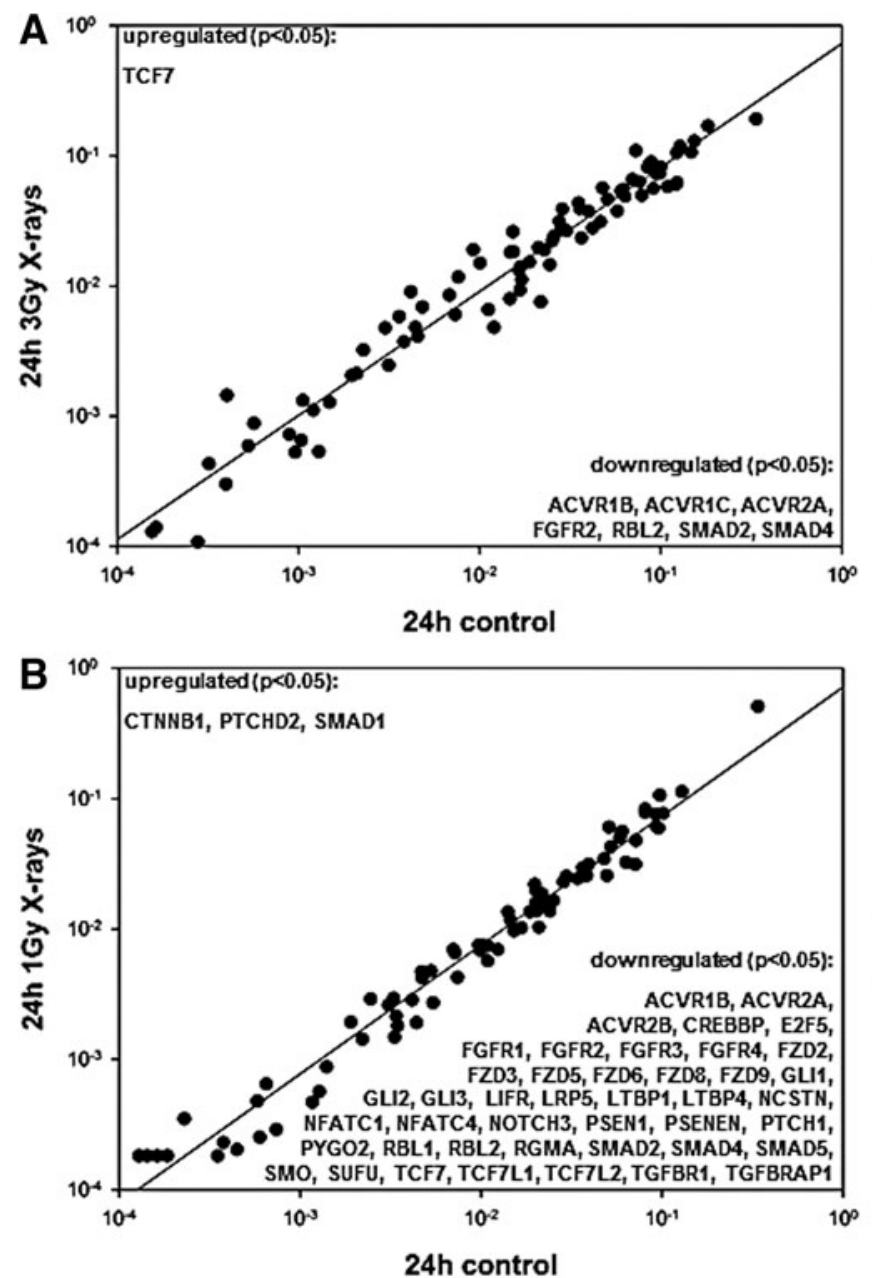

time PCR arrays. In this study, EP cells and MP cells displayed great differences. MP cells turned out to be much more sensitive than EP cells. Whereas the majority of MP cells died after a 3 Gy X-ray exposure (data not shown) hampering analyses after irradiation with this dose, EP cells easily tolerated doses up to $3 \mathrm{~Gy}$. In general, the EP controls showed high variations and, in part, clustered together with irradiated samples. In contrast, MP cells were clearly distinguishable from samples irradiated with 1 or $3 \mathrm{~Gy}$ X-rays (Fig. 4). Figure 5 shows the clustergrams of EP (Fig. 5A) and MP cells (Fig. 5B) indicating the significantly up- or downregulated stem cell signaling markers $24 \mathrm{~h}$ and 4 days postirradiation. Twenty-four hours after irradiation with 3 Gy X-rays, EP cells showed only few factors, mostly belonging to the transforming growth factor beta (TGF beta) pathway, to be significantly downregulated, while only transcription factor 7 (TCF7), a member of the Wnt pathway, was significantly upregulated. Four days after irradiation, more factors were significantly upor downregulated. In contrast, MP cells subjected to $1 \mathrm{~Gy}$ $\mathrm{X}$-rays showed the highest number of stem cell signaling regulators being downregulated $24 \mathrm{~h}$ after irradiation. Those factors belonged among others to the TGF beta, Wnt, Hedgehog, FGF, and Notch signaling pathways. Again, activin receptors
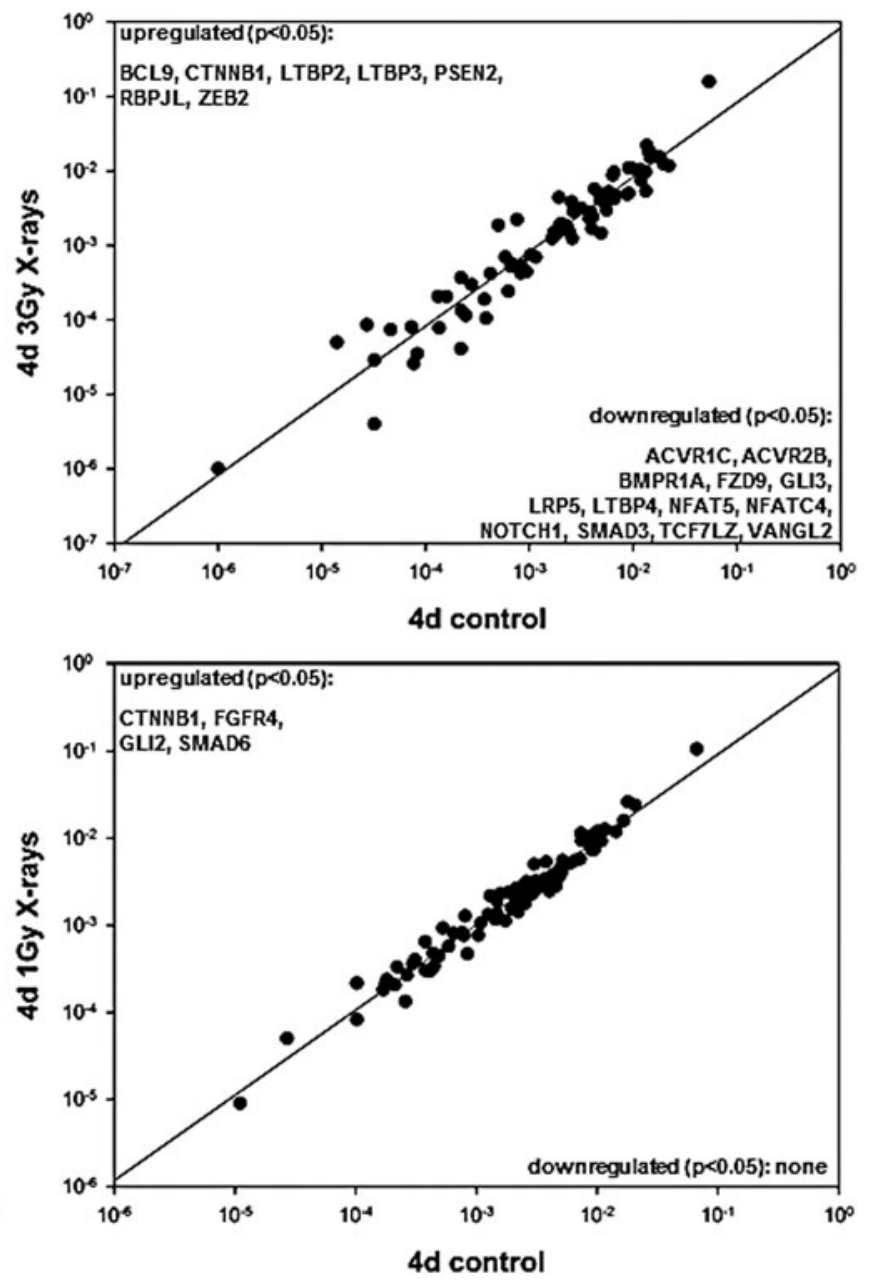

FIG. 5. Stem cell signaling array: fold-regulation gene expression analyses $\left(2^{-\Delta \Delta C T}\right)$. Significantly up- or downregulated genes according to the Student's $t$-test $(N=3, * P \leq 0.05)$ are listed in the corners of the dot plots. (A) Dot plots showing the fold regulation of exposed (3 Gy X-rays) versus sham-treated EP samples $24 \mathrm{~h}$ and 4 days postirradiation. (B) Dot plots showing the fold regulation of exposed ( $1 \mathrm{~Gy}$ X-rays) versus sham-treated MP samples $24 \mathrm{~h}$ and 4 days postirradiation. 
(ACVRs) were among the downregulated factors. In three out of four conditions (EP, 4 days, MP, $24 \mathrm{~h}$, and MP, 4 days), beta catenin 1 (CTNNB1) that encodes for an adherens junction protein anchoring the actin cytoskeleton was found to be significantly upregulated. Interestingly, while all of the downregulated transcripts in EP cells were also downregulated in MP cells $24 \mathrm{~h}$ after radiation treatment (with the exception of ACVR1C), this was not the case for TCF7, which by interacting with CTNNB1 promotes the differentiation of embryonic stem cells [22]. TCF7 was significantly upregulated in EP cells and significantly downregulated in MP cells $24 \mathrm{~h}$ after irradiation. Quantitative RT-PCR (Fig. 6) verified the downregulation of ACVR1B and ACVR2A in MP cells $24 \mathrm{~h}$ and 4 days after irradiation. Changes of the pluripotency markers octamer binding transcription factor 4 (OCT4) and NANOG were observed, but were not significant and less pronounced or even abrogated 4 days postirradiation.

\section{Altered differentiation into $D E$}

Due to the consistent downregulation of ACVRs that not only regulate stem cell maintenance but also are indispensable for the differentiation of hES cells into DE, we analyzed the capacity of MP H9 cells to form DE cells (Fig. 7). Characteristic for cells of this germ layer is the expression of SOX17 [SRY (sex determining region Y)-box 17], which is commonly used to select and purify DE cells [23,24] and the microRNA miR-375 [25]. In contrast, stromal derived factor 1 (SDF1) and AFP are expressed in embryonic ectoderm and mesoderm or extraembryonic endoderm, but not in DE [26] and, thus, served as negative markers.

In control cells, the expression of SOX17 mRNA peaked at day 3 and declined subsequently. Irradiated cells differentiated into DE showed the same expression pattern although with significantly lower expression levels at $\mathrm{d} 3$ and d5. Likewise, in the controls, the microRNA miR-375 ex- pression appeared at $\mathrm{d} 3$ and increased steadily to $\mathrm{d} 7$. In contrast, irradiated cells showed significantly lower miR375 expression that only marginally increased at $\mathrm{d} 7$. In addition, the amount of SDF1 in the controls was consistently lower from $\mathrm{d} 3$ to $\mathrm{d} 7$ than in their irradiated counterparts, while the expression pattern of AFP did not change substantially after irradiation.

\section{Discussion}

Exposure of the early embryo to IR potentially poses a great risk with serious developmental consequences. Doses to the embryo estimated to be in the range of $0.15-0.2$ Gy during the preimplantation and presomite stages may increase the risk of embryonic loss [27]. Indeed, counseling of pregnant women who have inadvertently been exposed to IR during very early pregnancy is based on the "all-or-none" concept that embryonic exposure that occurs before organogenesis results in either no adverse embryonic outcome or in embryonic death [28]. In agreement with this concept and many other studies [3-6], we observed an increase in apoptosis that even $24 \mathrm{~h}$ after irradiation still amounted to almost $50 \%$ in mechanically passaged hES cells and around $20 \%$ in enzymatically passaged ones. EP hES cells were less prone to IRinduced apoptosis than the mechanically passaged ones indicating a lowered sensitivity to genotoxic assaults as apoptosis is the main defense mechanism of pluripotent stem cells against DNA damage [29].

Even though apoptosis within the inner cell mass of the fertilized egg is a crucial process of mammalian development, it does not reach $>20 \%-30 \%$ under normal circumstances [30]. Thus, the degree of IR-induced apoptosis observed in this study might have led to a failure of the early embryo to implant and a subsequent termination of pregnancy in vivo. However, a survival of $50 \%-80 \%$ of cells subjected to $1-3 \mathrm{~Gy} \mathrm{X}$-rays warrants the question of how
FIG. 6. Quantitative RT-PCR analyses of pluripotency markers and genes, identified in the stem cell signaling array as significantly altered. Relative mRNA expression was analyzed using the standard curve method. 18S rRNA was used as a housekeeping gene (mean \pm $\mathrm{SD}, \quad N=3, * P \leq 0.05)$. RT-PCR, reverse transcription polymerase chain reaction.
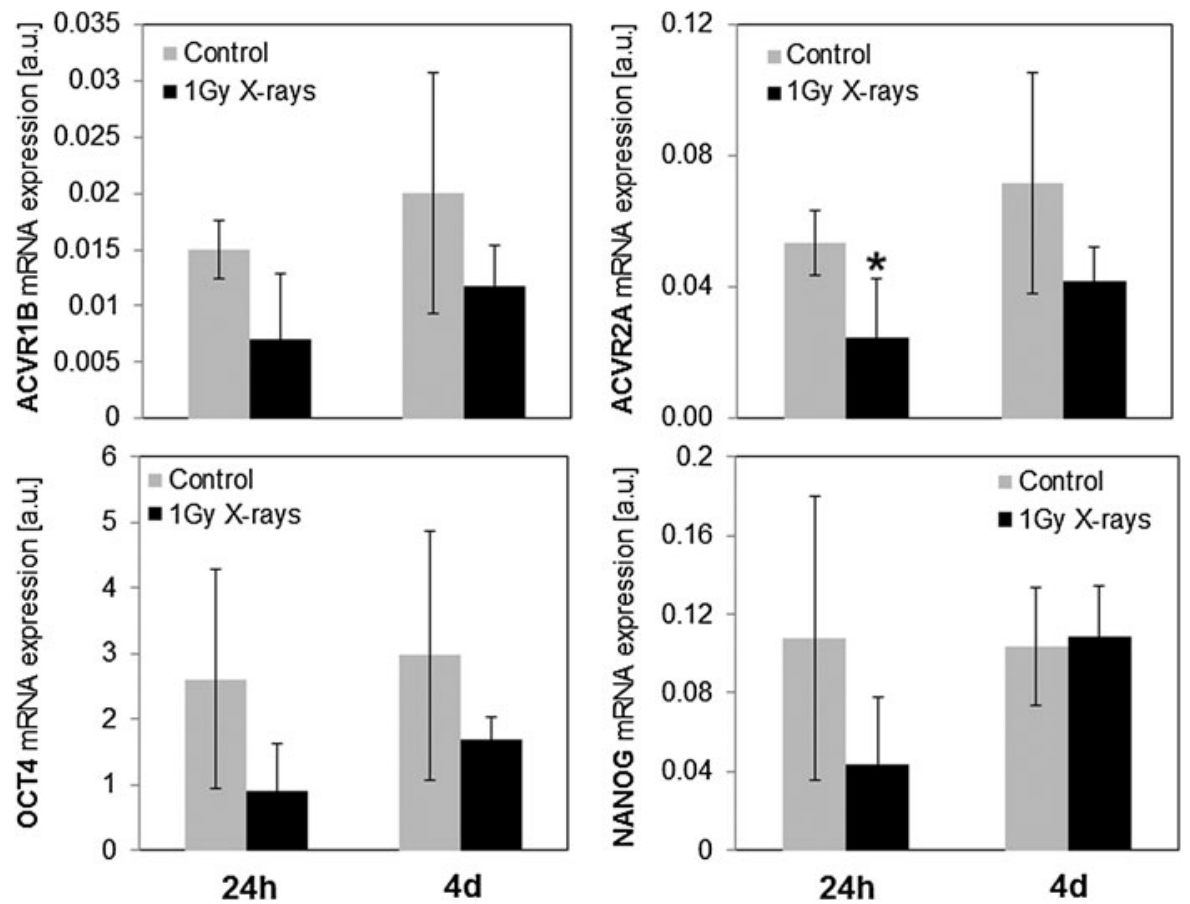

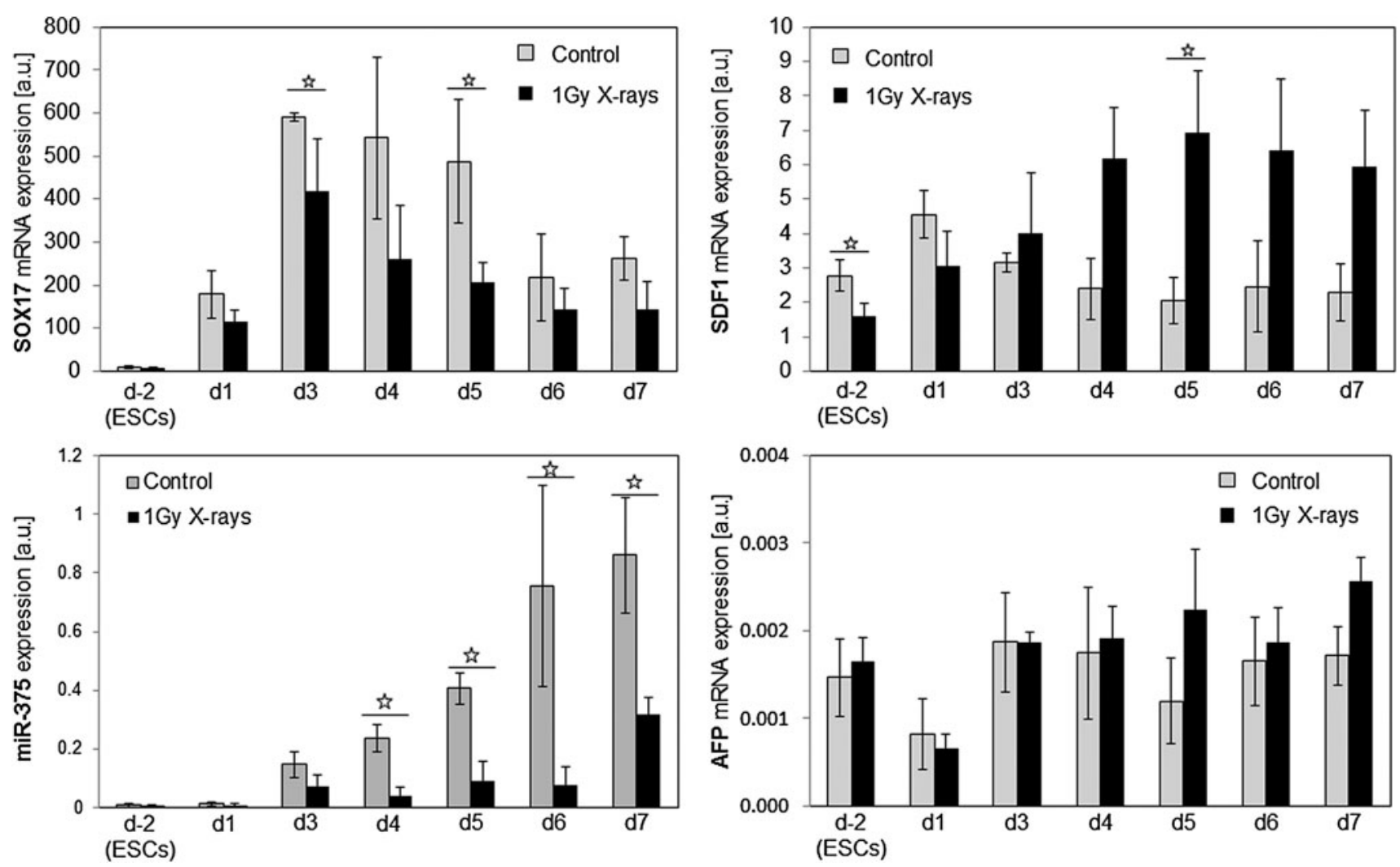

FIG. 7. Relative mRNA expression of endoderm markers and relative expression of microRNA miR-375. Relative mRNA expression (mean $\pm \mathrm{SD}$ of three independent experiments, $* P \leq 0.05$ ) was analyzed using the standard curve method. $18 \mathrm{~S}$ rRNA was used as a housekeeping gene in case of SOX17, SDF1, and AFP. SNORD25_11 served as a housekeeping gene for the normalization of miR-375. AFP, alphafetoprotein.

well these surviving hES cells maintain their pluripotent characteristics and subsequent differentiation capabilities that in an in vivo setting would assure normal development.

As indicated, after a transient arrest in G2/M phase that has also been observed by others [31], irradiated cells resumed normal cell cycle progression irrespective of the culture conditions used. It may be speculated that the transient arrest in G2 phase was a means of heightened DNA damage response by homologous recombination as seen in mouse ES cells [32], which has also been used intensively to improve gene editing in human pluripotent stem cells [33].

However, cytogenetic analyses $24 \mathrm{~h}$ postirradiation revealed an increase in chromosomal damage and it was more pronounced in EP cells than in MP cells (21 aberrations vs. 16 aberrations per 100 cells, respectively). Moreover, the number of complex aberrations was thrice higher in EP cells. In conjunction with the decreased level of apoptosis in EP cells, these results speak for an impaired clearance of damaged hES subpopulations. This is substantiated by the mFISH studies 4 days postirradiation. Even though in both groups the percentage of aberrant cells decreased significantly reflecting the elimination of aberrant cells, this process was more efficient in MP cells. Only two simple exchanges and one break per 197 cells (1.5 aberrations/100 cells) were observed in MP cells, while in EP cells four breaks, two simple, and three complex exchanges were found in 315 cells ( 2.9 aberrations/100 cells). The available data indicate that the observed distribution of breakpoints among individual chromosomes is random with respect to chromosome length/DNA content. Nonrandom accumulation of breakpoints in chromosomes such as chromosome $12,17,20$, and $\mathrm{X}$ as have been described for long-term culture of hES cells elsewhere [20] could not be detected in this study. Nonetheless, both the decreased sensitivity to apoptosis and the accompanying impairment to eliminate chromosomal damage in EP hES cells may render them unsuitable for adequate assessment of IR-induced biological effects as the EP cells do not represent bona fide hES cells in terms of their behavior to genotoxic stress.

This assumption was corroborated by the systematic assessment of important stem cell signaling factors regulating pluripotency, which is the first to be reported in hES cells after irradiation with X-rays. First, EP cells subjected to $3 \mathrm{~Gy} X$-rays displayed fewer expression changes $24 \mathrm{~h}$ postirradiation than MP hES cells irradiated with only $1 \mathrm{~Gy}$ X-rays. In principle, this was due to the huge heterogeneity of EP cells, in which nonirradiated controls, the majority of pluripotency markers were either expressed at the lowest or highest levels. Thus, they partly clustered together with irradiated samples. This was not the case in the MP culture condition, in which the control cells displayed the highest mRNA levels of pluripotency regulators and could be clearly distinguished from cells irradiated with 1 or 3 Gy X-rays that showed a dose-dependent decrease of expression for most of the markers analyzed.

The significant downregulation of stem cell signaling markers that comprised among others important members of 
the TGF beta-, Wnt-, and Hedgehog pathways that regulate pluripotency and the trend of downregulated Oct4 and Nanog $24 \mathrm{~h}$ postirradiation is in contrast to findings by others [34], who found even a significant increase of NANOG mRNA expression in $\mathrm{H} 9$ cells irradiated with 0.2 or $1 \mathrm{~Gy}$ of gamma radiation 17 and $65 \mathrm{~h}$ postirradiation while no significant changes in Oct 4 protein expression were detected. It can only be speculated whether this discrepancy is caused by the culture method that did include enzymatic passaging with collagenase IV or the differing radiation scheme.

In another study, pluripotency of irradiated H9 cells was assessed by teratoma formation upon transplantation into SCID mice [6], which was seen in all groups irradiated. However, although in vivo teratoma formation is the most stringent method to test the stem cells capability to differentiate into all three germ layers [35], it is not suitable to identify distinct pluripotency regulators or differentiation pathways that may be altered after exposure to IR. In this study, we identified for the first time players of pluripotency networks that are affected by IR.

Even though the majority of stem cell signaling regulators were impaired, there was a consistent upregulation of CTNNB1 even 4 days postirradiation regardless of the culture method. The CTNNB1 protein is part of a complex of proteins that constitute adherens junctions, which are necessary for the creation and maintenance of epithelial cell layers by regulating cell growth and adhesion between cells. In addition, forced expression of CTNNB1 stimulates human NANOG promoter activity by binding to the Tcf/Lef element in the enhancer region of the NANOG gene and ensures the NANOG expression [36]. This increased expression correlates with the recovery of the NANOG expression 4 days postirradiation and may represent a countermeasure of the cells to IR exposure. However, others found that CTNNB1 induction is correlated with early differentiation [37], which represents another possible reaction of hES cells to genotoxic stress [38].

Nonetheless, the many members of the stem cell signaling cascade that are downregulated clearly mirror the impairment of pluripotency maintaining networks. Particularly, ACVRs such as ACVR1B and ACVR2A were among those members consistently downregulated upon irradiation. Activins are members of the TGF-beta family of ligands that not only have an essential role in pluripotency maintenance but also in hES cell differentiation, specifically endoderm differentiation (reviewed in reference [39]). Activin A strongly binds to type 2 receptors such as ACVR2A, whereas the appropriate type 1 receptor is recruited thereafter [40]. It induces the expression of Oct4, Nanog, Nodal, Wnt family member 3 (Wnt3), bFGF, and FGF8 maintaining the stemness in hES cells [41]. Thus, downregulation of ACVRs after irradiation demonstrates the impairing role of IR on the maintenance of stemness.

Of particular interest, however, is the activin signaling as an inducer of endoderm differentiation. It has been shown that activin $\mathrm{A}$ is required for DE formation $[18,42,43]$. Its binding to the ACVRs and subsequent phosphorylation and activation of SMAD family members (SMAD) 2/3 lead to the direct transcriptional activation of a broad range of endoderm genes [44]. In contrast, through the SMAD2/3 signaling, the pluripotency factors NANOG, OCT4, and SOX2 control the expression of EOMESODERMIN (EOMES), which marks the onset of endoderm specification and in turn represses the expression of NANOG [45]. Due to this dual role of activin A signaling, we compared the capacity of irradiated MP hES cells and sham-irradiated controls to form DE after a recovery period of 4 days. Even though at the initiation of differentiation, most of the radiationinduced changes had been overcome, hES cells that survived irradiation had a markedly decreased capability to form $\mathrm{DE}$ as judged by the expression of the endoderm markers SOX17 [46] and microRNA miR-375 [25], while markers of extraembryonic endoderm such as SDF1 and AFP [26] were slightly elevated in cells that had undergone irradiation. Undoubtedly, this study affirms the negative impact of IR on the efficiency of hES cells to form DE.

\section{Conclusion}

The present study has shown that hES cells are a suitable tool for the IR risk assessment during early human development. However, careful choice of the culture methods and a vigorous monitoring of the stem cell quality are mandatory for the use of these cells and so far may not have been taken into account appropriately. Exposure to IR influences the properties of hES cells even when immediate radiation effects are overcome. This has been demonstrated at the level of pluripotency regulators and the specific differentiation into DE. Our results warrant consideration in the risk assessment of radiation effects during the earliest stages of human development and may indicate that there are exceptions to the rule of the "all-or-none" concept as has been indicated elsewhere [28].

\section{Acknowledgments}

The authors thank P. Hessel and J. Kunz for the excellent technical assistance. This work was funded by the German Ministry of Education and Research (grant 02NUK025A). S.L. was supported by HGS-HIRe.

\section{Author Disclosure Statement}

No competing financial interests exist.

\section{References}

1. Akhtar A. (2015). The flaws and human harms of animal experimentation. Camb Q Healthc Ethics 24:407-419.

2. Heinonen T. (2015). Better science with human cell-based organ and tissue models. Altern Lab Anim 43:29-38.

3. Lan ML, MM Acharya, KK Tran, J Bahari-Kashani, NH Patel, J Strnadel, E Giedzinski, and CL Limoli. (2012). Characterizing the radioresponse of pluripotent and multipotent human stem cells. PLoS One 7:e50048.

4. Luft S, D Pignalosa, E Nasonova, O Arrizabalaga, A Helm, M Durante, and S Ritter. (2014). Fate of D3 mouse embryonic stem cells exposed to X-rays or carbon ions. Mutat Res Genet Toxicol Environ Mutagen 760:56-63.

5. Sokolov M, V Nguyen, and R Neumann. (2015). Comparative analysis of whole-genome gene expression changes in cultured human embryonic stem cells in response to low, clinical diagnostic relevant, and high doses of ionizing radiation exposure. Int J Mol Sci 16:14737-14748.

6. Wilson KD, N Sun, M Huang, WY Zhang, AS Lee, Z Li, SX Wang, and JC Wu. (2010). Effects of ionizing radiation 
on self-renewal and pluripotency of human embryonic stem cells. Cancer Res 70:5539-5548.

7. Sokolov MV, IV Panyutin, IG Panyutin, and RD Neumann. (2011). Dynamics of the transcriptome response of cultured human embryonic stem cells to ionizing radiation exposure. Mutat Res 709-710:40-48.

8. Helm A, O Arrizabalaga, D Pignalosa, IS Schroeder, M Durante, and S Ritter. (2016). Ionizing radiation impacts on cardiac differentiation of mouse embryonic stem cells. Stem Cells Dev 25:178-188.

9. Rebuzzini P, L Fassina, F Mulas, R Bellazzi, CA Redi, LR Di, G Magenes, J Adjaye, M Zuccotti, and S Garagna. (2013). Mouse embryonic stem cells irradiated with gamma-rays differentiate into cardiomyocytes but with altered contractile properties. Mutat Res 756:37-45.

10. Rebuzzini P, M Zuccotti, CA Redi, and S Garagna. (2016). Achilles' heel of pluripotent stem cells: genetic, genomic and epigenetic variations during prolonged culture. Cell Mol Life Sci 73:2453-2466.

11. Chan EM, F Yates, LF Boyer, TM Schlaeger, and GQ Daley. (2008). Enhanced plating efficiency of trypsin-adapted human embryonic stem cells is reversible and independent of trisomy 12/17. Cloning Stem Cells 10:107-118.

12. Tosca L, O Feraud, A Magniez, C Bas, F Griscelli, A Bennaceur-Griscelli, and G Tachdjian. (2015). Genomic instability of human embryonic stem cell lines using different passaging culture methods. Mol Cytogenet 8:30.

13. Herszfeld D, E Wolvetang, E Langton-Bunker, TL Chung, AA Filipczyk, S Houssami, P Jamshidi, K Koh, AL Laslett, et al. (2006). CD30 is a survival factor and a biomarker for transformed human pluripotent stem cells. Nat Biotechnol 24:351-357.

14. Fazeli A, CG Liew, MM Matin, S Elliott, LF Jeanmeure, PC Wright, H Moore, and PW Andrews. (2011). Altered patterns of differentiation in karyotypically abnormal human embryonic stem cells. Int J Dev Biol 55:175-180.

15. Hartel C, A Nikoghosyan, M Durante, S Sommer, E Nasonova, C Fournier, R Lee, J Debus, D Schulz-Ertner, and S Ritter. (2010). Chromosomal aberrations in peripheral blood lymphocytes of prostate cancer patients treated with IMRT and carbon ions. Radiother Oncol 95:73-78.

16. Cornforth MN. (2001). Analyzing radiation-induced complex chromosome rearrangements by combinatorial painting. Radiat Res 155:643-659.

17. Savage JR. (1976). Classification and relationships of induced chromosomal structual changes. J Med Genet 13: 103-122.

18. Kroon E, LA Martinson, K Kadoya, AG Bang, OG Kelly, S Eliazer, H Young, M Richardson, NG Smart, et al. (2008). Pancreatic endoderm derived from human embryonic stem cells generates glucose-responsive insulin-secreting cells in vivo. Nat Biotechnol 26:443-452.

19. Pauklin S and L Vallier. (2013). The cell-cycle state of stem cells determines cell fate propensity. Cell 155:135-147.

20. Amps K, PW Andrews, G Anyfantis, L Armstrong, S Avery, H Baharvand, J Baker, D Baker, MB Munoz, et al. (2011). Screening ethnically diverse human embryonic stem cells identifies a chromosome 20 minimal amplicon conferring growth advantage. Nat Biotechnol 29:11321144.

21. Becker KA, PN Ghule, JA Therrien, JB Lian, JL Stein, AJ van Wijnen, and GS Stein. (2006). Self-renewal of human embryonic stem cells is supported by a shortened G1 cell cycle phase. J Cell Physiol 209:883-893.
22. Chatterjee SS, A Saj, T Gocha, M Murphy, FC Gonsalves, $X$ Zhang, P Hayward, OB Akgol, SS Shen, et al. (2015). Inhibition of beta-catenin-TCF1 interaction delays differentiation of mouse embryonic stem cells. J Cell Biol 211:39-51.

23. Schroeder IS, S Sulzbacher, T Nolden, J Fuchs, J Czarnota, R Meisterfeld, H Himmelbauer, and AM Wobus. (2012). Induction and selection of Sox17-expressing endoderm cells generated from murine embryonic stem cells. Cells Tissues Organs 195:507-523.

24. Wang P, KD McKnight, DJ Wong, RT Rodriguez, T Sugiyama, X Gu, A Ghodasara, K Qu, HY Chang, and SK Kim. (2012). A molecular signature for purified definitive endoderm guides differentiation and isolation of endoderm from mouse and human embryonic stem cells. Stem Cells Dev 21:2273-2287.

25. Hinton A, I Afrikanova, M Wilson, CC King, B Maurer, GW Yeo, A Hayek, and AE Pasquinelli. (2010). A distinct microRNA signature for definitive endoderm derived from human embryonic stem cells. Stem Cells Dev 19:797-807.

26. McGrath KE, AD Koniski, KM Maltby, JK McGann, and J Palis. (1999). Embryonic expression and function of the chemokine SDF-1 and its receptor, CXCR4. Dev Biol 213: 442-456.

27. Brent RL. (2015). Protection of the gametes embryo/fetus from prenatal radiation exposure. Health Phys 108:242-274.

28. Adam MP. (2012). The all-or-none phenomenon revisited. Birth Defects Res A Clin Mol Teratol 94:664-669.

29. Dumitru R, V Gama, BM Fagan, JJ Bower, V Swahari, LH Pevny, and M Deshmukh. (2012). Human embryonic stem cells have constitutively active Bax at the Golgi and are primed to undergo rapid apoptosis. Mol Cell 46:573-583.

30. Hardy K. (1997). Cell death in the mammalian blastocyst. Mol Hum Reprod 3:919-925.

31. Momcilovic O, L Knobloch, J Fornsaglio, S Varum, C Easley, and G Schatten. (2010). DNA damage responses in human induced pluripotent stem cells and embryonic stem cells. PLoS One 5:e13410.

32. Serrano L, L Liang, Y Chang, L Deng, C Maulion, S Nguyen, and JA Tischfield. (2011). Homologous recombination conserves DNA sequence integrity throughout the cell cycle in embryonic stem cells. Stem Cells Dev 20:363-374.

33. Yang D, MA Scavuzzo, J Chmielowiec, R Sharp, A Bajic, and M Borowiak. (2016). Enrichment of G2/M cell cycle phase in human pluripotent stem cells enhances HDRmediated gene repair with customizable endonucleases. Sci Rep 6:21264.

34. Sokolov MV, IV Panyutin, MI Onyshchenko, IG Panyutin, and RD Neumann. (2010). Expression of pluripotencyassociated genes in the surviving fraction of cultured human embryonic stem cells is not significantly affected by ionizing radiation. Gene 455:8-15.

35. Zhang WY, PE de Almeida, and JC Wu. (2008). Teratoma formation: a tool for monitoring pluripotency in stem cell research. In: Stem Book [Internet]. Cambridge (MA): Harvard Stem Cell Institute; 2008. Available from: www .ncbi.nlm.nih.gov/books/nbk133287/ DOI: 10.3824/stembook.1.53.1.

36. Kim CG, IY Chung, Y Lim, YH Lee, and SY Shin. (2011). A Tcf/Lef element within the enhancer region of the human NANOG gene plays a role in promoter activation. Biochem Biophys Res Commun 410:637-642.

37. Dravid G, Z Ye, H Hammond, G Chen, A Pyle, P Donovan, $\mathrm{X} \mathrm{Yu}$, and L Cheng. (2005). Defining the role of Wnt/ beta-catenin signaling in the survival, proliferation, and 
self-renewal of human embryonic stem cells. Stem Cells 23:1489-1501.

38. Rocha CR, LK Lerner, OK Okamoto, MC Marchetto, and CF Menck. (2013). The role of DNA repair in the pluripotency and differentiation of human stem cells. Mutat Res 752:25-35.

39. Pauklin $\mathrm{S}$ and L Vallier. (2015). Activin/Nodal signalling in stem cells. Development 142:607-619.

40. Olsen OE, KF Wader, H Hella, AK Mylin, I Turesson, I Nesthus, A Waage, A Sundan, and T Holien. (2015). Activin A inhibits BMP-signaling by binding ACVR2A and ACVR2B. Cell Commun Signal 13:27.

41. Xiao L, X Yuan, and SJ Sharkis. (2006). Activin A maintains self-renewal and regulates fibroblast growth factor, Wnt, and bone morphogenic protein pathways in human embryonic stem cells. Stem Cells 24:1476-1486.

42. D'Amour KA, AG Bang, S Eliazer, OG Kelly, AD Agulnick, NG Smart, MA Moorman, E Kroon, MK Carpenter, and EE Baetge. (2006). Production of pancreatic hormoneexpressing endocrine cells from human embryonic stem cells. Nat Biotechnol 24:1392-1401.

43. Kubo A, K Shinozaki, JM Shannon, V Kouskoff, M Kennedy, S Woo, HJ Fehling, and G Keller. (2004). Development of definitive endoderm from embryonic stem cells in culture. Development 131:1651-1662.

44. Brown S, A Teo, S Pauklin, N Hannan, CH Cho, B Lim, L Vardy, NR Dunn, M Trotter, R Pedersen, and L Vallier.
(2011). Activin/Nodal signaling controls divergent transcriptional networks in human embryonic stem cells and in endoderm progenitors. Stem Cells 29:1176-1185.

45. Teo AK, SJ Arnold, MW Trotter, S Brown, LT Ang, Z Chng, EJ Robertson, NR Dunn, and L Vallier. (2011). Pluripotency factors regulate definitive endoderm specification through eomesodermin. Genes Dev 25:238-250.

46. Aksoy I, R Jauch, J Chen, M Dyla, U Divakar, GK Bogu, R Teo, CK Leng Ng, W Herath, et al. (2013). Oct4 switches partnering from Sox 2 to Sox 17 to reinterpret the enhancer code and specify endoderm. EMBO J 32:938-953.

Address correspondence to: Dr. Insa S. Schroeder

Department of Biophysics GSI Helmholtz Center for Heavy Ion Research Planckstraße 1 Darmstadt 64291 Germany

E-mail: i.schroeder@gsi.de

Received for publication September 23, 2016

Accepted after revision November 15, 2016

Prepublished on Liebert Instant Online December 10, 2016 